\title{
Canonical correlation analysis applied to production and reproduction traits of meat type quails
}

\author{
Análise de correlações canônicas aplicada em características de \\ produção e reprodução em codorna de corte
}

\author{
Jeferson Corrêa Ribeiro' ${ }^{I}$ Luciano Pinheiro da Silva ${ }^{\text {II }}$ Giovani da Costa Caetano ${ }^{\text {III }}$ \\ Aline Camporez Crispim ${ }^{\text {III }}$ Rodrigo de Oliveira Pacheco ${ }^{\text {III }}$ Robledo de Almeida Torres ${ }^{\text {III }}$
}

\section{ABSTRACT}

Data from 629 meat type quails were used to study association between two different sets of traits: egg production and reproduction. Traits related to reproduction were: body weight at 42 days (W42), average egg weight (AEW), age at sexual maturity $(A S M)$; and production traits: number of eggs produced from 42 until $182^{\text {th }}$ day considering intervals of 35 days each period $(P 1$, P2, P3 and P4). Canonical correlations were used to describe the association between these two sets of traits. The canonical coefficients indicated that egg production and reproductive traits were moderately related (0.3475). The first partial period of production (PI) and age at sexual maturity were the most relevant traits among the analyzed variables. Results show that selecting animals with lower age at sexual maturity might lead to an increase on number of eggs produced until 77 days, although it might also lead to a decrease on egg weight. Breeding programs aiming to improve quails production should consider selection strategies to decrease age at sexual maturity and then, as correlated response, increased egg production might be observed.

Key words: animal breeding, canonical pairs, Coturnix coturnix, egg production, multivariate analysis.

\section{RESUMO}

Dados de 629 matrizes de codornas de corte foram utilizados para estudar a associação entre características de reprodução e produção de ovos. As características analisadas foram: peso corporal aos 42 dias (W42), peso médio de ovos (AEW) e idade à maturidade sexual (ASM), que compôs as características reprodutivas; e números de ovos produzidos a partir do $42^{\circ}$ dia divididos em intervalos de 35 dias cada (P1, P2, P3 e P4), que integrou o grupo de características de produção. Para análise de associação, foi utilizada a análise de correlação canônica entre os dois conjuntos de características. Os coeficientes canônicos indicaram que os conjuntos de características de produção de ovos e reprodutivas são dependentes, correlacionando-se moderadamente (0,3475). Entre as variáveis avaliadas, o primeiro periodo parcial de produção de ovos e a idade à maturidade sexual foram as mais importantes. Os resultados indicam que a seleção para menor idade à maturidade sexual resultaria em aumento no número de ovos produzidos até 77 dias de idade, embora essa seleção possa resultar em diminuição do peso de ovo. Conclui-se que a seleção de aves deve ser efetuada para menor maturidade sexual, pois, assim, estará selecionando também aves para maior produção de ovos.

Palavras-chave: análise multivariada, Coturnix coturnix melhoramento animal, pares canônicos, produção de ovos.

\section{INTRODUCTION}

Quails have been widely used in studies involving genetic selection due to its short interval generation, high fertility and small size (YANG et al., 1998). Moreover, they present physiological and genetic similarity with chicken with the advantage of fast development of specialized lines at specific traits, what would not be possible using animals of Gallus genus (MINVIELLE, 2009). These points make the use of quail as animal model preferable. Several traits can be included on breeding programs, and a large number of them are directly influenced by environment (BARBOSA et al., 2005), difficulting interpretation through univariate analysis

IDepartamento de Zootecnia, Instituto Federal Goiano, 75650-000, Morrinhos, GO, Brasil. E-mail: jeferson.ribeiro@ifgoiano.edu.br. Corresponding author.

IIDepartamento de Zootecnia, Universidade Federal do Ceará (UFC), Fortaleza, CE, Brasil.

IIIDepartamento de Zootecnia, Universidade Federal de Viçosa (UFV), Viçosa, MG, Brasil. 
(SAKAGUTI et al., 1996). An alternative in this case is the use of multivariate analysis.

Multivariate analysis allows evaluation of traits simultaneously, taking into account its correlations. Thus, it becomes possible to infer about a set of traits by considering a known significance level (SAKAGUTI et al., 1996), as well as to estimate a better combination of variables that leads to a significant value. GODSHALK \& TIMOTHY (1988) describe the use of multivariate analysis techniques as an alternative of selection index in plants, which the main advantage is to provide weights to the traits without needing to estimate genetic parameters on the population of interest.

Canonical correlation is a multivariate analysis technique based on determining two linear combinations, each one for a set of variables, maximizing the correlation coefficient between them. Firstly, the objective is to determine a pair of linear combinations that presents the highest correlation. Therefore, to determine the pair of linear combinations that provide the higher correlation between all the other not correlated pairs and the pair previously selected, and so on. The linear combination pairs are defined as canonical variables and their correlations as canonical correlations. These combinations are canonical variables, and these pairs are denominated as canonical pairs (JOHNSON \& WICHERN, 2007).

Among traits with economic relevance on genetic evaluation of breeders, egg production, sexual maturity and average egg weight are well known by their connection with profit determination. Age at sexual maturity, body weight, laying persistence and egg weight can influence egg production. Considering this, canonical correlation analysis may allow inferences about one sets of features that might affect another one. Furthermore, canonical correlation analysis enables to indicate traits that most have influence on other traits.

On a briefly review of literature, canonical correlation analysis have been used on pigs studies (BARBOSA et al., 2005; VENTURA et al., 2011; VENTURA et al., 2012), buffalos (THOMAS \& CHAKRAVARTY, 2000), dairy cattle (KESKIN et al., 2004, ÇANKAYA \& KAYAALP, 2007, ÇANKAYA et al., 2008a), lambs (SAHIN et al., 2011) and laying hens (YANG et al., 1998; AKBAS \& TAKMA, 2005; ROSÁRIO et al., 2006; MENDES \& AKKARTAL, 2007; ÇANKAYA et al., 2008b). The aim of this study was to estimate the relation between productive and reproductive traits; to determine which are most relevant on meat type quail selection, leading to higher number off eggs through canonical correlation analysis.

\section{MATERIALS E METHODS}

Data from 629 females totalizing four generations of meat type quails (Coturnix coturnix), from a poultry breeding program at Universidade Federal de Viçosa were used. Diets for laying quail contained $19 \%$ of crude protein and $2900 \mathrm{kcal}$ of metabolizable energy per kg. Quails had free access to water and feed and lighting program was 16 hours of light.

Egg production data were collected daily. Age at sexual maturity (ASM) was considered as the age that the bird laid the first egg. The number of eggs produced was recorded starting on $42^{\text {th }}$ until $182^{\text {th }}$ days of age, divided on intervals of 35 days each, totalizing four periods. All birds were weighed at $42^{\text {th }}$ day of age (W42). The average egg weight (AEW) for each period was the average egg weight in a sample of three days record. Animals were weighed on a 0.01 precision scale.

All traits recorded were separated in two sets. The first set with egg production traits, such as number of eggs produced from $43^{\text {th }}-77^{\text {th }}, 78^{\text {th }}-112^{\text {th }}$, $113^{\text {th }}-147^{\text {th }}$ and $148^{\text {th }}-182^{\text {th }}$ days of age, relative to first partial period (P1), second partial period ( $\mathrm{P} 2)$, third partial period (P3) and fourth partial period (P4), respectively. The second set with reproductive traits, such as: average egg weigh (AEW), age at sexual maturity (ASM) and female body weight at maturity (W42).

The first step was the estimation of Pearson's correlation among variables. Both Pearson's correlation and canonical correlation analysis were obtained using CANCORR procedure from SAS software (SAS, 2009). Canonical correlation analysis was performed to analyze the relation between the two sets of traits (productive and reproductive). This technique was developed by Hotteling, in 1935, and consists on obtaining the optimal correlation between a linear combination of a set of variables $\left(Y_{\mathrm{i}}\right)$ and another linear combination of set of variables $\left(X_{\mathrm{i}}\right)$. Therefore, it is possible to define that the linear combination of set of variables, following JOHNSON \& WICHERN (2007) are:

$$
\begin{aligned}
& U_{1}=a_{11} X_{1}+a_{12} X_{2}+\ldots+a_{1 p} X_{p} \\
& V_{1}=b_{11} Y_{1}+b_{12} Y_{2}+\ldots+b_{1 q} Y_{q}
\end{aligned}
$$

Canonical variables $\mathrm{U}_{1}$ and $\mathrm{V}_{1}$ belong to the first canonical pair associated with the first canonical correlation, expressed for: 


$$
r_{1}=\frac{\operatorname{Cov}\left(U_{1}, V_{1}\right)}{\sqrt{\hat{V}\left(U_{1}\right) \cdot \hat{V}\left(V_{1}\right)}}
$$

The percentage of variance explained by the canonical variable $U_{x}^{2}$ and $V_{Y}^{2}$ is determined by:

$$
U_{X_{i}}^{2}=\frac{\sum_{j=1}^{p} a_{i j}^{2}}{p} \quad V_{Y_{i}}^{2}=\frac{\sum_{j=1}^{q} b_{i j}^{2}}{q}
$$

$\mathrm{p}$ and $\mathrm{q}$ are the number of variables from $\mathrm{X}$ and $\mathrm{Y}$, respectively.

To check for significance of canonical correlation, maximum likelihood ratio test was performed, considering Lambda $(\Lambda)$ from Wilk's whose expressions are presented by KHATTREE \& NAIK (2000).

\section{RESULTS AND DISCUSSION}

Correlation analysis was performed to avoid the severe multicollinearity or linear dependency between the variables, excluding those with correlation higher than 0.80 according to MONTGOMERY \& PECK (2012). The third period (P3) from egg production traits was eliminated because it caused severe multicollinearity, which leads to singular matrices or poorly conditioned matrices.

Bivariate correlation among analyzed traits is on table 1 . The highest correlation was between P2 and P4 (0.8024), while the lowest was between $\mathrm{P} 1$ and ASM $(-0.5653)$. These results indicate that a higher number off eggs produced on the second period results on higher number of eggs on fourth period as well. Furthermore, lower age at sexual maturity imply on higher number of eggs produced until 77 days of age. Similar results involving correlation between sexual maturity and number off eggs were presented by AKBAS \& TAKMA (2005) and ÇANKAYA et al. (2008b) on studies with laying hens.

The standardized coefficients, canonical correlation (r), squared canonical correlation $\left(\mathrm{r}^{2}\right)$ and statistical test $(\mathrm{F})$ to canonical pairs between egg production and reproductive traits are on table 2 .

Sets of traits related to egg production and reproduction were not considered independent (Table 2). Only the first canonical correlation was significant $(\mathrm{p}<0.01)$ and it was 0.3475 , showing moderate correlation between reproductive and productive traits. Evaluating traits within first canonical pair there was a high predominance of P1 that is related to egg production and age at sexual maturityin the set of reproductive traits. Proportion of variance in common to the two canonical variables at the first canonical pair, given by squared canonical correlation coefficient $\left(\mathrm{r}^{2}\right)$ was $12.8 \%$.

After choice of the most appropriate canonical pair, the second step was to analyze the magnitude of canonical coefficients that would be significant on contributions relative with correlated variable. Coefficients indicated effect of reproductive traits on productive traits (Table 3 ). Through the correlation between the original variable and their canonical correlation, P1 still the most important variable on canonical variable $U_{1}$, as well as age at sexual maturity still the most relevant variable on $\mathrm{V}_{1}$. Thus, lower age at sexual maturity provides higher number of eggs until 77 days.

Age at first egg is an important trait, because it characterizes sexual maturity in females, which have influence of several relevant factors on

Table 1 - Bivariate correlation considering productive and reproductive traits.

\begin{tabular}{lllllll}
\hline & P1 & P2 & P4 & ASM & AEW & W42 \\
\hline P1 & 1.000 & & & & & \\
P2 & $0.7195^{*}$ & 1.000 & & & & \\
P4 & $0.4720^{*}$ & $0.8024^{*}$ & 1.000 & 1.000 & 1.000 & \\
ASM & $-0.5653^{*}$ & $-0.3390^{*}$ & $-0.1811^{*}$ & 0.0003 & 0.0877 & 1.000 \\
AEW & 0.0566 & 0.0134 & -0.0440 & -0.0011 & \\
W42 & -0.0541 & -0.0589 & -0.0747 & & \\
\hline
\end{tabular}

* = significance $(\mathrm{P}<0.001)$.

P1 - number of eggs produced at first period; P2 - number of eggs produced at second period; P4 - number of eggs produced at fourth period; ASM - age at sexual maturity; AEW - average egg weight; W42 - body weight at 42 days of age. 
Table 2 - Standardized coefficients, canonical correlation (r), squared canonical correlation $\left(\mathrm{r}^{2}\right)$ and $\mathrm{F}$ statistical test $(\mathrm{F})$ to canonical pairs relative to productive and reproductive traits.

\begin{tabular}{lccc}
\hline Traits & & & \\
& $1^{\text {st }}$ & $2^{\text {nd }}$ & \\
\hline P1 & -1.2160 & -0.0487 & -0.8641 \\
P2 & 0.3362 & -0.7518 & 2.0595 \\
P4 & 0.0050 & 1.5082 & -0.8803 \\
ASM & 0.9906 & -0.0420 & 0.1302 \\
AEW & -0.1202 & -0.7753 & 0.6279 \\
W42 & 0.0953 & -0.5583 & -0.8302 \\
r & 0.3475 & 0.0088 & 0.0003 \\
F & $<0.0001^{*}$ & 0.2827 & 0.6829 \\
$r^{2}$ & 0.1208 & $7.84 \times 10^{-5}$ & $9.24 \times 10^{-8}$ \\
\hline
\end{tabular}

${ }^{*}=$ significance $(\mathrm{P}<0.001)$.

P1 - number of eggs produced at first period; P2 - number of eggs produced at second period; P4 - number of eggs produced at fourth period; ASM - age at sexual maturity; AEW - average egg weight; W42 - body weight at 42 days of age.

poultry production. According to LIU et al. (1995), the beginning of egg production can be affected by genetics, chronological age and body composition. When the bird reaches sexual maturity it means that reproductive organs developed enough, enabling birds to produce eggs. Early development of reproductive organs may lead to higher egg production and total egg number.

Although age at sexual maturity had been highlighted on the set of reproductive traits, it is important to consider also body weight at maturity. Birds with reasonable weight may persist better laying eggs. According to LEESON \& SUMMERS (1997), birds that present a higher body weight at sexual maturity might have better performance and in contrast birds with lower body weight might present later sexual maturity as well as lower performance.

On the other hand, average egg weight had a negative correlation on egg production at first period. RIBEIRO et al. (2012) corroborate these results, when obtained lower egg weights and lower egg mass evaluating the same period of age. Similar results were found by ÇANKAYA et al. (2008).

AKBAS \& TAKMA (2005) conclude that age at sexual maturity and body weight at maturity had a positive impact on number of eggs produced on different periods, while egg weight have a negative impact on number of egg. Therefore, it is desirable to select birds that achieve sexual maturity earlier in life, indirectly selecting birds with better egg production.

Table 3 - Correlation between: productive traits (P1, P2 and P4) and their canonical variables (U); reproductive traits (ASM, AEW and W42) and their canonical variables $(\mathrm{V})$; canonical variables and traits.

\begin{tabular}{lccccccc}
\hline & $\mathrm{U}_{1}$ & $\mathrm{U}_{2}$ & $\mathrm{U}_{3}$ & & $\mathrm{~V}_{1}$ & $\mathrm{~V}_{2}$ & \\
\hline P1 & -0.9716 & 0.1217 & 0.2031 & $\mathrm{ASM}$ & 0.9893 & -0.0397 & 0.1403 \\
P2 & -0.5351 & 0.4272 & 0.7289 & AEW & -0.1070 & -0.8307 & 0.5463 \\
P4 & -0.2981 & 0.8799 & 0.3699 & $\mathrm{~W} 42$ & 0.0742 & -0.6346 & -0.7693 \\
ASM & 0.5832 & -0.0037 & 0.0024 & $\mathrm{P} 1$ & -0.5727 & 0.0115 \\
AEW & -0.0631 & -0.0782 & 0.0095 & $\mathrm{P} 2$ & -0.3154 & 0.0402 & 0.0035 \\
W42 & 0.0438 & -0.0597 & -0.0134 & $\mathrm{P} 4$ & -0.1757 & 0.0828 \\
\hline
\end{tabular}

P1 - number of eggs produced at first period; P2 - number of eggs produced at second period; P4 - number of eggs produced at fourth period; ASM - age at sexual maturity; AEW - average egg weight; W42 - body weight at 42 days of age. 


\section{CONCLUSION}

Canonical coefficients indicate that the sets of traits related to production and reproductive traits are dependents. Among analyzed variables, egg production until 77 days of age and age at sexual maturity were the most important traits for selection of meat type quails focused on higher egg production. Thus, selection to decrease the age at sexual maturity could lead to an increase of number of eggs.

\section{BIOETHICS AND COMMITTEE APPROVAL}

The protocol of experiments using animals is in accordance with CONEA and was approved by ethical committee from Universidade Federal de Viçosa, protocol number $73 / 2014$.

\section{ACKNOWLEDGEMENTS}

We thank the Conselho Nacional de Desenvolvimento Científico e Tecnológico (CNPq), process 142696/2010-2, Coordenação de Aperfeiçoamento de Pessoal de Nível Superior (CAPES) and Fundação de Amparo à Pesquisa do estado de Minas Gerais (FAPEMIG) for financial support.

\section{REFERENCES}

AKBAS, Y.; TAKMA, Ç. Canonical correlation analysis for studying the relationship between egg production traits and body weight, egg weight and age at sexual maturity in layers. Czech Journal Animal Science, v.50, n.4, p.163-168, 2005. Available from: $<$ http://www. cazv.cz/attachments/4-Akbas.pdf>. Accessed: Jan. 09, 2015.

BARBOSA, L. et al. Association between performance and carcass traits of swine using canonical correlation. Brazilian Journal of Animal Science, v.34, n.6, p.2218-2224, 2005. Available from: <http://www.scielo.br/scielo.php?pid=S151635982005000700008\&sccript $=$ sci_arttext $>$. Accessed: Jan. 10, 2015. doi: $10.1590 / \mathrm{S} 1516-35982005000700008$.

CANKAYA, S.; KAYAALP, G.T. Estimation of relationship between live weights and some body measurements in german farm $\mathrm{x}$ hair crossbred by canonical correlation analysis. Journal of Animal Production, v.48, n.2, p.27-32, 2007. Available from: <http://www.zooteknidernegi.org/dergi/icerik/ makale/2007_48_2_27-32.pdf $>$. Accessed: Nov. 12, 2014.

ÇANKAYA, L.S. et al. Canonical correlation analysis for estimation of relationship between some body measurements at the birth and 6 month periods in holstein friesian calves. Journal Animal and Veterinary Advances, v.7, n.8, p.953-958, 2008a. Available from: <http://medwelljournals.com/abstract/?doi=jav aa.2008.953.958>. Accessed: Nov. 12, 2014.

ÇANKAYA, S. et al. Canonical correlation analysis for estimation of relationships between sexual maturity and egg production traits upon availability of nutrients in pullets. Asian-Australasian
Journal Animal Science, v.21, n.11, p.1576-1584, 2008b. Available from: <http://dx.doi.org/10.5713/ajas.2008.80106>. Accessed: Nov. 12, 2014.

GODSHALK, E.B.; TIMOTHY, D.H. Factor and principal component analyses as alternatives to index selection. Theoretical and Applied Genetics, v.76, p.352-360, 1988. Available from: $\quad<$ http://link.springer.com/article/10.1007/BF00265334>. Accessed: Nov. 08, 2014.

JOHNSON R.A.; WICHERN D.W. Applied multivariate statistical analysis. 6.ed. Upper Saddle River: Pearson, 2007. 773p.

KESKIN, I. et al. Canonical correlation analysis for studying the relationship between reproductive traits and milk yield traits of brown Swiss herd raised at the state farm of konuklar in konya province. Journal of Animal and Veterinary Advances, v.3, n.12, p.797-799, 2004. Available: <http:// medwelljournal.com/abstract/?doi=javaa.2004.797799>. Accessed: Nov. 08, 2014.

KHATTREE, R.; NAIK, D.N. Multivariate data reduction and discrimination with SAS software. New York: SAS Institute, 2000. 584p.

LEESON, S.; SUMMERS, J.D. Commercial poultry nutrition. 2.ed. Ontario: University Books, 1997. 350p.

LIU, G. et al. Correlated responses to long-term divergent selection for eight-week body weight in chickens: growth, sexual maturity and egg production. Poultry Science, v.74, p.1259-1268, 1995. Available from: <http:// ps.oxfordjournals.org/content/74/8/1259.full.pdf $>$. Accessed: 12 Jan. 2015

MENDES M.; AKKARTAL, E. Canonical correlation analysis for studying the relationships between pre- and post-slaughter traits of Ross 308 broiler chickens. Archives Geflügelk, v.71, n.6, p.267-271, 2007. Available from: <http://www.europeanpoultryscience.com/artikel.dll/m07-04mk_NDIxODIxMA. PDF>. Accessed: Nov. 07, 2014

MINVIELLE, F. What is quail good for in a chicken-focused world? World's Poultry Science Journal, v.65, p.601-608, 2009. Available from: $<$ http://dx.doi.org/10.1017/S0043933909000415>. Accessed: Oct. 03, 2014.

MONTGOMERY, D.C.; PECK, E.A. Introduction to linear regression analysis. 5.ed. New York: Willey, 2012. 672p.

RIBEIRO, J.C. et al. Genetic evaluation for egg mass in partial periods and complete period in meat quails. Revista Brasileira de Zootecnia, v.41, n.5, p.1158-1162, 2012. Available from: <http://www.scielo.br/pdf/rbz/v41n5/12. pdf $>$. Accessed: Jan. 12, 2015. doi: 10.1590/S151635982012000500012 .

ROSÁRIO, M.F. et al. Canonical discriminant analysis applied to broiler chicken performance. Animal, v.2, n.3, p.419-424, 2008. Available from: <http://www.lce.esalq.usp.br/tadeu/Millor Silva_Coelho_Savino_Tadeu.pdf>. Accessed: Jan. 10, 2015. doi: $10.1017 / \mathrm{S} 175173110 \overline{7001012 .}$

SAHIN, M. et al. Canonical correlation analysis for estimation of relationships between some traits measure dat weaning time and six-month age in merino lambs. Bulgarian Journal of 
Agricultural Science, v.17, n.5, p.680-686, 2011. Available from: $<$ http://www.agrojournal.org/17/05-15-11.pdf $>$. Accessed: Dec. 02, 2015. doi: 10.1017/S1751731107001012.

SAKAGUTI, E.S. et al. Evaluation of tests of multivariate analysis of variance in experiments with unbalanced data. Brazilian Journal of Animal Science, v.25, p.437-448, 1996. Available from: <http://www.revista.sbz.org.br/artigo/visualizar. php?artigo=238>. Accessed: Jan. 10, 2015.

THOMAS P.R.; CHAKRAVARTY, A.K. Canonical correlation analysis for studying the association of breeding efficiency and breeding values with growth and reproductive traits of murrah buffaloes. Indian Jounal Animal Research, v.34, n.2, p.100-103, 2000. Available from: $<\mathrm{http}: / / \mathrm{www}$.indianjournals.com/ijor.aspx? target $=$ ijor:ijar $1 \&$ volume $=34 \&$ issue $=2 \&$ articl e $=003>$. Accessed: Jan. 10, 2015.
VENTURA, H.T. et al. Canonical correlation analysis of the association between carcass and ham traits in pigs used to produce dry-cured ham. Genetics and Molecular Biology, v.34, n.3, p.451-455, 2011. Available from: <http://dx.doi.org/10.1590/ S1415-47572011000300014>. Accessed: Jan. 05, 2015.

VENTURA, H.T. et al. Use of multivariate analysis to evaluate genetic groups of pigs for dry-cured ham production. Livestock Science, v.148, p.214-220, 2012. Available from: $<$ http://dx.doi.org/10.1016/j.livsci.2012.06.007>. Accessed: Jan. 05, 2015.

YANG, N. et al. Forty generations of bidirectional selection for mating frequency in male japanese quail. Poultry Science, v.77, p.1469-1477, 1998. Available from: <http:// ps.oxfordjournals.org/content/77/10/1469.full.pdf $>$. Accessed: Jan. 09, 2015 